\title{
INDONESIAN HATCHERY REARED SEABASS LARVAE (Lates calcarifer), ASSOCIATED WITH VIRAL NERVOUS NECROSIS (VNN)
}

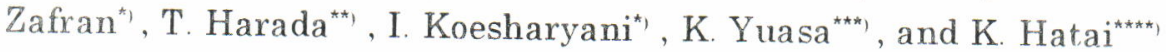

\begin{abstract}
Mass mortality amongs seabass larvae, Lates calcarifer, reared in hatcheries in East Java and Bali due to viral nervous necrosis were investigated. Outbreaks of the disease occurred from August to November 1997. Each time the disease occurred, cumulative mortality of the larvae reached $100 \%$. Infected fish were characterized by abnormal behaviour such as swimming upside down or sinking to the bottom. Bacteria or parasites associated with the disease were not detected in infected fish. Histopathologically, necrosis and vacuolation in the brain and retina were observed. Abundant spherical viral particles, $30 \mathrm{~nm}$ in diameter. were found in the cytoplasm of affected nerve cells. These findings revealed that the mortalities among seabass larvae were due to viral nervous necrosis (VNN) caused by nodavirus.
\end{abstract}

KEYWORDS: seabass, Lates calcarifer, viral nervous necrosis, nodavirus.

\section{INTRODUCTION}

Seed production techniques for various marine fish and shellfish have been developed in Indonesia. Seabass, Lates calcarifer is one of the species marked as new and potential commodity for aquaculture. However, mass mortality in the larval stages due to unidentified diseases have led to frequent decreases in production in recent years.

In 1997, mass mortalities of seabass larvae, Lates calcarifer occurred at hatcheries in Situbondo, East Java, and in Gerokgak, Bali in August and then in Banyuwangi in November. The mortality rate reached $100 \%$ in all cases. Clinical signs of the infected fish were characterized by abnormal behavior such as swimming upside down or sinking to the bottom.

Mass mortalities in seabass larvae due to a viral infection called viral nervous necrosis (VNN) (Glazebrook et al., 1990; Renaulte et al., 1991; Munday et al., 1992) have been reported in Australia and the Mediterranean. VNN has also been reported in a wild variety of cultured marine fish species, and has caused serious damage to the industry in Japan (Yoshikoshi \& Inoue, 1990; Mori et al., 1991).

In this study, a histopathological study of the mass mortalities at three seabass hatcheries in Indonesia was conducted to elucidate the cause of the mortalities.

\section{MATERIALS AND METHODS}

\section{Fish Examined}

One to two-month-old larvae of seabass reared in East Java and Bali showing abnormal behavior such as swimming upside down or sinking to the bottom, were examined for this study. The origin of the eggs distributed to the these hatcheries identical. Water temperatures were $27-29^{\circ} \mathrm{C}$ when outbreaks of the disease occurred.

\section{Parasitological and Bacteriological Examinations}

The gills and body surface were examined for parasites by using light microscope. Bacteria from the liver and brain were isolated using marine agar and TCBS agar, then incubated at $27^{\circ} \mathrm{C}$ and $35^{\prime \prime} \mathrm{C}$ respectively for 48 hours.

\section{Histological Examination}

About 20 of moribund seabass larvae from each hatchery were used for histological examination and 5 were used for observation transmission electron microscopy. The whole body of moribund larvae was fixed in 10\% phosphate buffered formalin. The sample was then embedded in paraffin wax and the section was stained with haematoxylin-eosin ( $\mathrm{H} \& \mathrm{E})$. For transmission electron microscopy, the sample was re-fixed in a $2.5 \%$ glutaraldehyde- $2 \%$ paraformaldehyde mixture ( $\mathrm{pH} 7.4$ ), then post-fixed with $1 \%$ osmium

\footnotetext{
*) Comdol Resenrch Stution for Coustal Fisheries

**) Division of Biology, Nippon Veterinary and Animal Science University

$* * *$ ) Japan International (Goperation Agency (ATA-37!)

****) Division of Fish Disenses, Nippon Veterinary and Animal Science University
} 
tetroxide, and embedded in Quetol 812. A thin section was stained with $1 \%$ uranyl acetate and $1 \%$ lead citrate, then examined by electron microscope.

\section{RESULTS AND DISCUSSION}

\section{Parasitological and Bacteriological Examinations}

Neither parasites nor bacteria were detected from the fish samples.

\section{Histopathological Examination}

All of the examined fish showed same histopathological appearance. Vacuolation and degeneration of nerve cells were observed in the

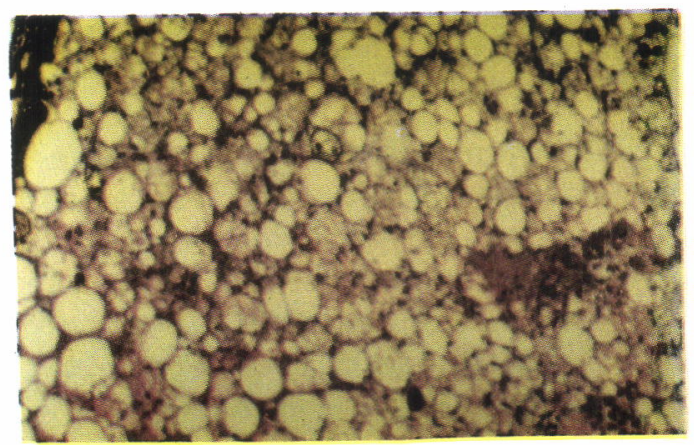

Figure 1. Light microscopy showing necrosis and vacuolation in the brain of diseased seabass larvae (H\&E, x 100). brain (Figure 1) and retina (Figure 2), but no histopathological changes were observed in other organs. Numerous round-shaped, unenveloped virus particles, about $30 \mathrm{~nm}$ in diameter, were observed in the cytoplasm of the degenerated nerve cells (Figure 3 ). In both the brain and retina, the virions had the same size and morphology. Normal appearance of the brain and retina of seabass was shown in Figure 4.

Recently, a viral infection, viral nervous necrosis (VNN) was reported in larvae and juveniles of Japanese parrotfish (Yoshikoshi \& Inoue, 1990), in stripped jack (Mori et al., 1992), larvae and juveniles of redspotted grouper (Mori et al., 1991), kelp grouper and tiger puffer (Nakai et al., 1994), adult sevenband grouper (Fukuda et al., 1996), barramundi in Australia (Glazebrook et al., 1990;

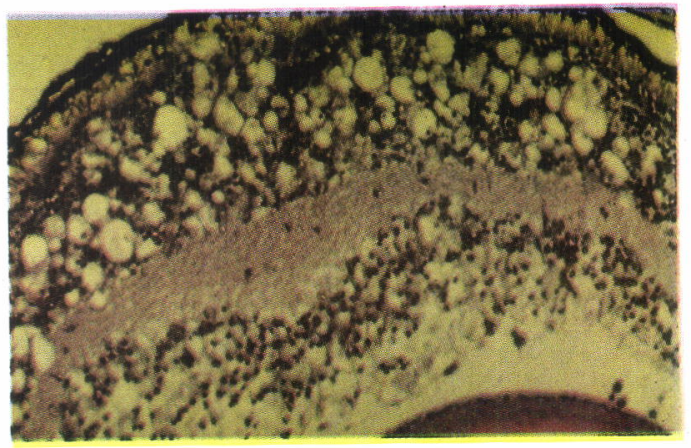

Figure 2. Light microscopy showing necrosis and vacuolation in the retina of a diseased seabass larvae $(H \& E, x$ 100).

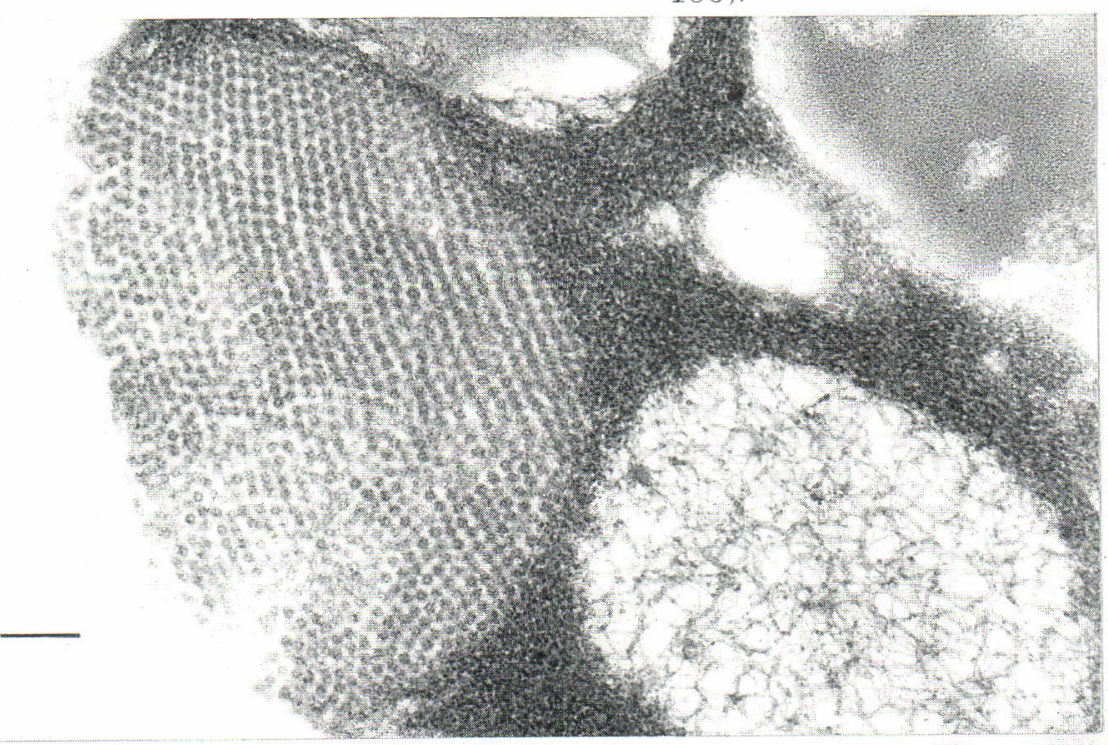

Figure 3. Electron micrographs showing numerous virus particle in the cytoplasm of a retinal cell 


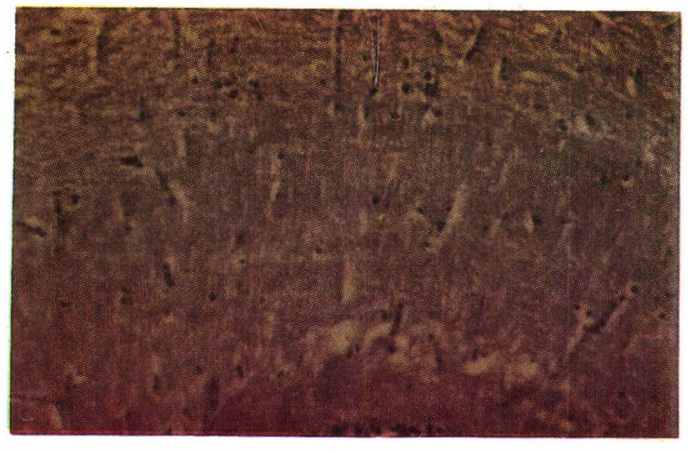

(a)

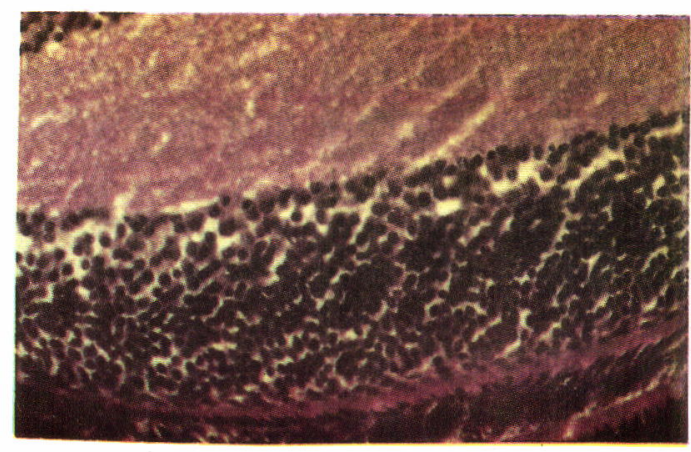

(b)

Figure 4. Light microscopy showing normal appearance of the brain (a) and retina (b) of a healthy seabass larvae (H\&E, x 100).

Munday et al., 1992; Munday \& Owens, 1997), larvae and juveniles of seabass in France (Breuil et al., 1991), and in Tahiti (Renault et al., 1991). The causative virus VNN was tentatively identified as picorna-like virus/picornaviridae (Glazebrook et al., 1990; Mori et al., 1991; Breuil et al., 1991) while more recent publications identified it as nodavirus/ nodaviridae (Mori et al., 1992; Nakai et al., 1994; Fukuda et al., 1996; Nguyen et al., 1996; Munday \& Owens, 1997). The VNN disease was characterized by abnormal swimming behaviour such as a whirling or corkscrew motion, heavy vacuolation of the central nervous tissue, and spherical virus particle $(25-30 \mathrm{~nm}$ in diameter) observed in the cyptoplasm of affected nerve cells (Nakai et al., 1995 in Fukuda et al., 1996). Fukuda et al. (1996) reported that fish infected with VNN were characterized by upside down swimming behaviour, swimbladder inflation and degeneration of nervous tissue (necrosis and vacuolation).

In the present study, the infected fish were characterized by abnormal swimming or sinking to the bottom, anorexia, slight blackening of the body, and degeneration of brain tissue and retina (necrosis and vacuolation). No parasites nor bacteria associated with the disease were found, but small round-shaped virus particles ( $30 \mathrm{~nm}$ in diameter) were observed in the cytoplasm of affected nerve cells in the central nervous tissues and retina from all samples. These findings are identical as VNN infection cases reported before (Yoshikoshi \& Inoue, 1990; Mori et al., 1991; 1992; Nakai et al., 1994; Fukuda et al., 1991; 1996; Glazebrook et al., 1990; Munday et al., 1992; Munday \& Owens, 1997; Breuil et al., 1991; Renault et al., 1991). This indicates, that present seabass disease was associated with VNN. This is the first report of VNN of seabass larvae reared in a hatchery in Indonesia

Fukuda et al. (1996) suspected a higher rearing water temperature in summer season $\left(25-28^{\circ} \mathrm{C}\right)$ is a possible predisposing factor which enabled the viral invasion into the central nervous system. Mori et al. (1991) also reported that disease occurred in larval and juveniles of redspotted grouper were reared at $25-27^{\circ} \mathrm{C}$ in August to September. The effect of rearing water temperature on the defence mechanisms of seabass larvae should be examined in further experiments.

VNN in Japan was detected from gonads of broodstocks (Mori et al., 1997; Watanabe et al., 1997), indicating possible vertical transmission of the virus from spawners to the offsprings. One effective method to prevent VNN is by using broodstocks free of the virus in the hatchery. But, Glazebrook et al. (1990) reported that the virus is highly infectious, being transmitted from diseased to healthy fish within 4 days of contact. Up to now, no chemical agent has been found effective against this disease.

\section{REFERENCES}

Breuil, G., Bonami, J.R., Pepin, J.F. and Pichot, Y. 1991. Viral infection (Picorna-like virus) associated with mass mortalities in hatchery-reared sea-bass (Dicentrarchus labrax) larvae and juveniles. Arquaculture 97: 109-116

Fukuda, Y., Nguyen, H.D., Furuhashi, M. and Nakai. T. 1996. Mass mortality of cultured sevenband grouper. Epinephelus septemfasciatus, associated with viral nervous necrosis. Fish Pathol. 31(3): $165 \cdot 170$. 


\section{Zafran, T. Harada, I. Koesharyani, K. Yuasa, and K. Hatai}

Glazebrook, J.S.. Heasman. M.P. and de Beer, S.W 1990. Picorna-like viral particles associated with mass mortalities in larval barramundi. Lates calcarifer Bloch. J. Fish. Dis. 13: 245.249.

Mori, K., Nakai, T.. Nagahara, M., Muroga, K. Mekuchi. T. and Kanno. T. 1991. A viral diseuse in hatchery-reured larvae and juvenile of redspotted grouper. Gyobyo Kenkyu 26(4): 209-210.

Mori, K.. Nakai, T., Muroga, K.. Arimoto, M. Mushiake, K. and Furusawu, I. 1992. Properties of a new virus belonging to Nodaviridue found in larval stripped jack (Pseudocaranx dentex) with nervous necrosis. Virol. 187: 368-371.

Mori, K., Mushiake, K. and Arimoto, M. 1997. Current control methods of viral nervous necrosis in stripped jack. Pseudocaranx dentex. Abstract of International Symposium on Dissedse in Marine Aquaculture. Hiroshima, October 3.6. 1997.

Munday. B.L.. Langdon, J.S., Hyatt, A. and Humphrey. J.D. 1992. Mass mortality ussociated with a viral-induced vacuolating encephalopathy and retinopa thy of larval and juvenile barramundi, Lates calcarifer Bloch. Aglucuculture 103: 197-211.

Munday, B.L. and Owens. L. 1997. Viral diseases of fish and shellfish in Australia. Abstract of International Symposium on Disease in Marine. Aquaculture. Hiroshima, October 3.6, 1997.
Nakai, T., Nguyen. H.D., Nishizawa, T., Muroga, K., Arimoto, M. and Ootsuki, K. 1994. Occurrence of viral nervous necrosis in kelp grouper and tiger puffer. Fish Pathol. 29(3): 211-212.

Nguyen, H.D. Nakai, T. and Muroga, K. 1996 Progression of striped jack nervous necrosis virus (SJNNV) infection in naturally and experimentally infected stripped jack Pseudocaranx dentex larvae. Dis. Aquaculture Org. 24: 99-105.

Renault, T., Haffner P., Laurencin, F.B., Breuil, G and Bonami. J.R. 1991. Mass mortalities in hatchery-reared sea bass (Lates calcarifer) larvae associated with the presence in the brain and retina of virus-like particles. Bull. Eur. Ass. Fish Pathol. 11(2): 68.73.

Watanabe, K., Suzuki, S., Suzuki, K., Nishizawa, T. Yoshimizu, M. and Ezura, Y. 1997. Control of viral nervous necrosis of burfin flounder by selection of virus free broodstocks in the hatchery. Abstract of International Symposium on Disease in Marine. Aquaculture. Hiroshima, October 3.6, 1997.

Yoshikoshi, K. and Inoue, K. 1990. Viral nervous necrosis in hatchery-reared larvae and juveniles of Japanese parrotfish, Oplegnathus fasciatus (Temminck \& Schlegel). J. Fish Dis. 13: 69.77. 